\title{
The effect of oxygen depletion on the timing and magnitude of blue-green algal blooms
}

\author{
A. M. Trimber and E. E. Prepas
}

With 2 figures and 2 tables in the text

\section{Introduction}

In lakes, blue-green algae may form surface scums, produce unpleasant tastes and odors, and are an unsatisfactory food source for many organisms higher in the trophic structure (REYNOLDs \& W ALSBY 1975, KEATING 1978, HoRNE 1979). Hypotheses to explain the success of blue-green algae include: 1) the excretion of organic compounds that suppress growth of other algae (MurpHY et al. 1976, KeATING 1978), 2) the minimization of mortality through an immunity to grazing by zooplankton (PORTER 1973, KALFF \& KNOECHEL 1978) and 3) superior uptake kinetics for inorganic carbon (King 1970, Shapiro 1973, 1984). More recently, the competitive advantage of blue-green algae under conditions of nitrogen limitation (FLETr et al. 1980, SCHINDrer 1977, SMITH 1983, 1986) has been emphasized. However, Trmabee \& Prepas (1987) have shown that for many lakes, total phosphorus (TP) may be as good or a better indicator of the relative biomass of blue-green algae than total nitrogen (TN) or TN: TP ratios. Variance in TP accounted for $63 \%$ of the variance in the relative biomass of blue-green algae. A substantial portion of the variance $(37 \%)$ in the relative biomass of blue-green algae is still unaccounted for.

To understand the factors controlling maximum blue-green algal biomass, we focused on processes leading up to the bloom rather than the bloom itself. Recruitment can be very important for blue-green algal blooms in comparison to other algal blooms (Trumber \& Harris 1984). With the possible exception of Aphanizomenon flosaquae (Lynch \& Shapiro 1981, Trimber \& Harkis 1984), the recruitment of benthic overwintering colonies or filaments of blue-green algae, is enhanced by anoxic conditions over lake sediments (Rernolds et al. 1981, Trumbee \& Harris 1984). Anoxic conditions should favor the development of blue-green algal blooms. In addition, anoxic conditions over lake sediments may results in increased TP concentrations in the hypolimnion (Prepas \& $x$ VICKERY 1984). When lake mixing occurs, this accumulated TP is transferred to the epilimnion (Rir.eY \& Prepas 1984) and promotes algal growth. The aim of this study was to evaluate whether the timing and extent of oxygen depletion over lake sediments could serve as predictors of the timing and magnitude of summer blue-green algal blooms in freshwater North temperate lakes. Data on the extent of oxygen depletion over lake sediments, mean depth, trophogenic total phosphorus and the relative biomass of blue-green algae were collected from thirty-nine lakes.

\section{Materials and methods}

Information on spring and summer (May to September) euphotic or epilimnetic blue-green algal biomass and total phytoplankton biomass or the relative biomass of blue-green algae, total phosphorus (TP), mean depth (z) and depth to $20 \%$ dissolved oxygen saturation in the deepest part of the lake were obtained from twenty-two Canadian lakes, 16, 3, and 3 in Alberta, Saskatchewan and Ontario; six American lakes, 5 in New York State, 1 in Wisconsin; and four Swedish lakes. Data for the Alberta lakes were obtained from R. S. Anderson, D. Beliveau, A. Furnell and P. Mitchell unpublished data, Alberta Environment; A. Trumber and E. E. Prepas unpublished data and from Prepas \& Trew (1983) and Trew et al. (1981). These lakes were sampled from 5 to 11 times over the spring and summer. Data for the Saskatchewan lakes were obtained from TrEw (1985; unpublished data, Alberta Environment). These lakes were sampled only once in early August 1984. Data for the Ontario lakes were obtained from Nalewajko et al. (1981), Trimber (1983; unpublished) and CHrisTIE (1974). Data for the New York lakes were obtained from Schaffer \& OGLesby (1978), BAN- 
NISTER \& BUBECK (1978), HaRR et al. (1978) and AutenBach et al. (1978). Data for the Wisconsin lake were from Brock (1986) and for the Swedish lakes were from Coveney et al. (1977), ENEL (1980) and WILLEN (1975).

We calculated an index of the relative potential for blue-green algal recruitment from lake sed iments based on the assumptions that:

1. as lake mean depth increase, the relative proportion of lake sediment area to volume decreases. The recruitment of blue-green algae should therefore decrease as lake mean depth increases.

2. as the proportion of lake sediments overlain by oxic water increases, the recruitment of bluegreen algae should decrease. To estimate the proportion of lake sediments in contact with oxic water, the depth to low dissolved oxygen levels (ie $<20 \%$ dissolved oxygen saturation or $<2 \mathrm{mg} \cdot \mathrm{I}^{-1} \mathrm{O}_{2}$ ) was divided by the maximum lake depth. We used $2 \mathrm{mg} \cdot 1^{-1} \mathrm{O}_{2}$ to represent anoxic conditions because lower dissolved oxygen levels could not be accurately measured with the meters used to collect the data. These two assumptions were combined to yield an index (OXYD, m) of the relative potential for recruitment of blue-green algae:

$$
\mathrm{OXYD}=\text { proportion of sediments overlain by oxic water }{ }^{*} \overline{\mathrm{z}}
$$

We predicted that recruitment and therefore the relative biomass of blue-green algae would be inversely correlated to the average OXYD.

To approximate a normal distribution, the relative blue-green algal biomass was transformed:

$$
\mathrm{BG} \text { Index }=\ln [\% \mathrm{BG} /(100-\% \mathrm{BG})]
$$

where \%BG is the percent of the total phytoplankton biomass made up to blue-green algae. BG index can range from $-4.595(\% \mathrm{BG}=1)$ to $4.595(\% \mathrm{BG}=99)$. OXYD values were transformed to $\log _{10}$ to stabilize the variance, linearize the data and to improve the distribution.

\section{Results}

We evaluated whether our index of the potential for blue-green algal recruitment from lake sediments could be used to predict the relative biomass of blue-green algae. A significant correlation was observed between the average May to September OXYD and the relative biomass of blue-green algae $(\mathrm{r}=-0.57, \mathrm{p}<0.001)$ (Fig. 1). A significant correlation was also observed between $\bar{z}$ and the relative biomass of blue-green algae $(\mathrm{r}=-0.58, \mathrm{p}<0.001)$.

In thirteen of the thirty-nine lakes examined, the lake sediments were always overlain by well oxygenated water and the average OXYD was equal to $\bar{z}$ (Table 1). In four of these lakes, $\bar{z}$ was $<5 \mathrm{~m}$. In these shallow lakes, which may mix intermittently, it is possible that anoxic conditions developed over lake sediments but they were missed due to the sampling interval. In the other twenty-six lakes examined, oxygen depletion over lake sediments was observed and therefore the average OXYD was $<\bar{z}$ (Table 2). In these lakes, three patterns were observed:

1. Blue-green algal biomass increased as OXYD decreased: even though trophogenic total phosphorus (TP) did not increase until after maximum blue-green algal biomass occurred. This pattern was observed in highly stratified lakes such as Ethel Lake, Alberta (Fig. 2) or lakes where TP levels did not increase in the hypolimnion in response to oxygen depletion over lake sediments (e.g. Guelph Lake, Ontario). We defined a TP increase as a $20 \%$ elevation over June levels.

2. Blue-green algal biomass increased as OXYD decreased prior to an increase in $T P$ in the trophogenic zone. Increased TP levels in the trophogenic zone occurred at or prior to the date that the maximum blue-green algal biomass was observed.

3. Blue-green algal biomass increased coincident with a decrease in OXYD and an increase in TP in the trophogenic zone. 


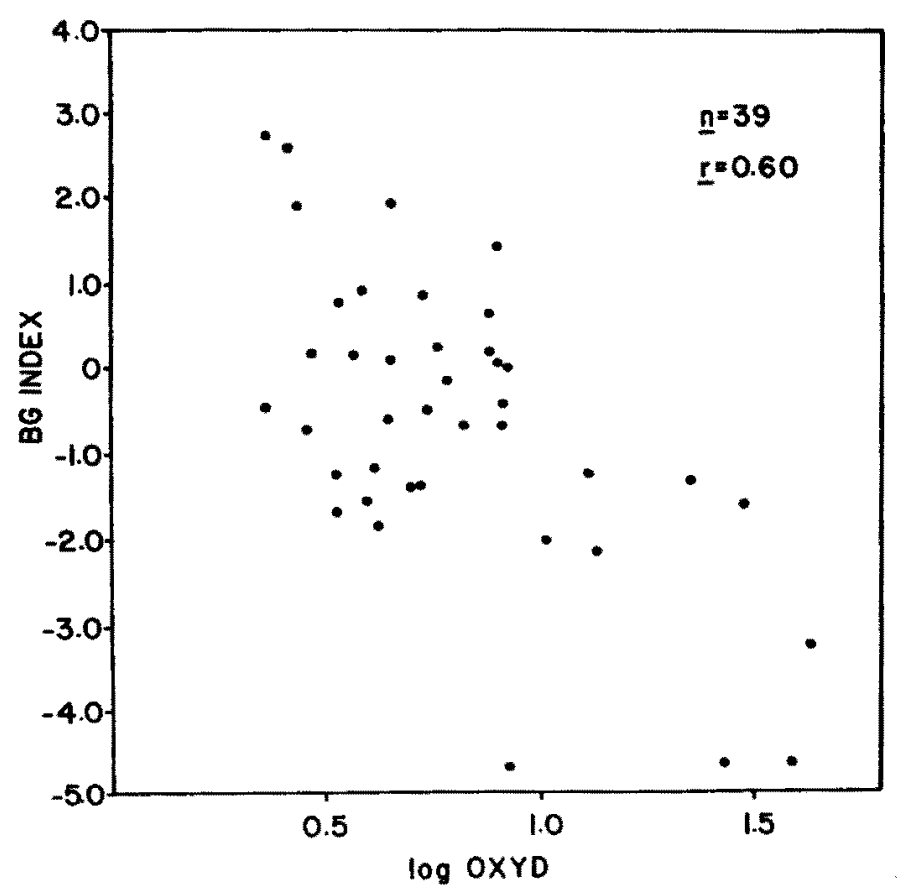

Fig. 1. Relation between the average May to September relative potential for blue-green algal recruitment from lake sediments $(\mathrm{OXYD}, \mathrm{m})$ and the average relative bluegreen algal biomass $(\mathrm{BG}$ Index).

Table 1. Study lakes with no evidence for oxygen depletion over lake sediments in the deepest part of the lake in summer. Mean depth (z) and average relative biomass of blue-green algae (\% BG) are indicated.

\begin{tabular}{lllcc}
\hline Lake & Year & Location & \% BG & $\bar{z}(\mathrm{~m})$ \\
\hline Lepine & 84 & Sask., CAN & 1 & 4.2 \\
Nakamun & 83 & Alta., CAN & 72 & 4.5 \\
Isle & 83 & Alta., CAN & 55 & 4.5 \\
Gull & 83 & Alta., CAN & 21 & 4.9 \\
Hjälmaren & 72 & Sweden & 43 & 6.1 \\
Mälaren & 72 & Sweden & 23 & 13.0 \\
Hemlock & 73 & N.Y., USA & 11 & 13.6 \\
Pierce & 84 & Sask., CAN & 22 & 22.8 \\
Owasco & 84 & N.Y., USA & 18 & 29.3 \\
Vänern & 72 & Sweden & 1 & 27.0 \\
Vattern & 72 & Sweden & 1 & 39.0 \\
Skaneateles & 73 & N.Y., USA & 4 & 43.5 \\
\hline
\end{tabular}

The onset of oxygen depletion over lake sediments, with or without a concomitant phosphorus release into the trophogenic zone triggered the development of blue-green algae in lake phytoplankton. The relative biomass of blue-green algae was very high $(\vec{x}=65 \%)$ in lakes where oxygen depletion resulted in almost immediate increases in trophogenic TP (Group 3, Table 2). Maximum blue-green algal biomass occurred from 1 
Table 2. Study lakes where oxygen depletion occurred over lake sediments in the deepest part of the lake in the summer. OXYD refers to the average depth to $<20 \%$ dissolved oxygen saturation or $<2 \mathrm{mg} \cdot 1^{-1} \mathrm{O}_{2}$ divided by the maximum depth multiplied by mean depth ( $\left.\bar{z}\right)$. \%BG is the average relative blue-green algal biomass. LAG is the length of time between the date that the average OXYD was reached and the date that the maximum blue-green algal biomass was observed. For lakes in group 1, blue-green algal biomass increased as OXYD decreased: trophogenic total phosphorus (TP) levels remained unchanged. For lakes in group 2, blue-green algal biomass increased as OXYD decreased prior to an increase in trophogenic TP. For lakes in group 3, blue-green algal biomass increased coincident with a decrease in OXYD and an increase in trophogenic TP.

\begin{tabular}{llllll}
\hline Lake Year Location & $\% \mathrm{BG}$ & $\overline{\mathrm{z}}(\mathrm{m})$ & $\begin{array}{l}\text { OXYD } \\
(\mathrm{m})\end{array}$ & $\begin{array}{l}\text { LAG } \\
\text { (weeks) }\end{array}$ \\
\hline
\end{tabular}

a) Group 1

Amisk

Bysjon

Ethel

Ethel

\section{Ethel}

Guelph

Island S.

Lake-on-the-mountain

Mendota

Mendota

Mendota

b) Group 2

Battle

Baptiste $S$.

c) Group 3

Baptiste N.

Buck

Heart

LaBiche

LaNonne

Nakamun

Pine

Tucker

Wizard
Alta., CAN

\section{Sweden}

Alta, CAN

Alta., CAN

Alta., CAN

Ont., CAN

Alta., CAN

Ont., CAN

Wisc., USA

Wisc., USA

Wisc., USA

Alra., CAN

Alta, CAN

Alra., CAN

Alta., CAN

Ont., CAN

Alta., CAN

Alta, CAN

Alta., CAN

Alta, CAN

Alta., CAN

Alta, CAN

\section{5}

94

38

16

23

70

18

67

57

65

41

38

51

24

57

93

81

71

87

26

88

55

79

10.7
3.6
6.6
6.6
6.6
4.1
5.2
10.0
12.4
12.4
12.4

\section{6}

2.3

2.3

3.3

3.3

3.4

3.9

7.6

7.7

8.1

8.1

5.5

12.7

5.4

8.4

4.1

5.8

3.8

8.0

5.2

3.8

5.2

2.7

3.7

5.0

3.7

P data or $\underline{n}<5$ )

\begin{tabular}{ll} 
Canadarago & 68 \\
Des Isles & 84 \\
Hilda & 8 \\
Irondequoit B. & 7 \\
Saratoga & 72 \\
\hline
\end{tabular}

N.Y., USA

Sask., CAN

Alta., CAN

N.Y.USA

N.Y., USA

54
12
34
56
37

\begin{tabular}{rrr}
10.0 & 7.8 & \\
14.1 & 10.6 & \\
6.2 & 2.8 & \\
6.8 & 3.0 & 4 \\
8.0 & 4.4 & 8 \\
\hline
\end{tabular}

to 15 weeks after the date that OXYD reached the average May to September value (Table 2). In some cases, the time lag is a minimum value, since it was not known whether blue-green algal biomass had peaked by the last sample date.

\section{Discussion}

Aeration of the hypolimnion or destratification of the water column to decrease bluegreen algal blooms has been suggested and tried with variable success many times (e.g., Nicholls et al. 1980, Horne 1979). The rationale has usually been to neutralize the buoyancy advantage of blue-green algae in stable water columns, to increase $\mathrm{CO}_{2}$ or to 

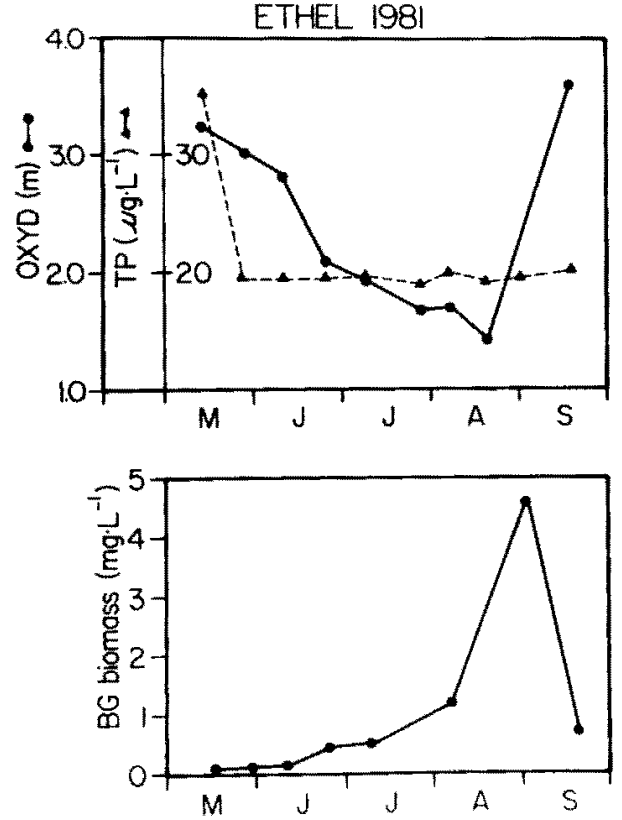

Fig. 2. Seasonal pattern of the relative potential for blue-green algal recruitment from lake sediments (OXYD, m), trophogenic total phosphorus (TP) and blue-green algal biomass in a highly, thermally statified lake.

reduce the sediment release of nutrients such as phosphorus or iron. In many cases, aeration is done after the bloom is already present. Our results suggest that aeration of the lake sediments should be done before blue-green algae are abundant. In some lakes, increases in blue-green algae were observed after the onset of oxygen depletion over lake sediments and prior to increases in total phosphorus in the trophogenic zone. While our data set is small, the significant relation between $O X Y D$ and the BG Index, suggests that the relative potential for blue-green algal recruitment, influences the relative biomass of blue-green algae. This is consistent with observations that dissolved oxygen depletion over the sediments favors the recruitment of blue-green algae. Further research is needed into the factors affecting recruitment of blue-green algae and the effect of altered recruitment on the eventual maximum standing crop of blue-green algae.

\section{Acknowledgements}

We thank D. O. Trew, P. Mrtchell, R. S. Anderson, D. Beurveau and A. Furneu (Alberta Environment, Pollution Control Division, Water Quality Control Branch) for the use of their unpublished data and P. Chambers for commenting on a draft of this manuscript. A. M. Trimber was supported while doing this work by a grant from Alberta Environment Research Trust and the work was supported by an operating grant from the Natural Sciences and Engineering Research Council and a contract from the Research Management Division of Alberta Environment to E. E. Prepas.

\section{References}

Aulenbach, D. B., Cuesceri, N. L. \& Ferris, J. J., 1978: Limnology of Saratoga Lake. - In: J. A. Bloomfred. (ed.) Lakes of New York State. Vol. III: Ecology of the Lakes of East-Central New York: 265-390. Academic Press. 
BANMISTER, T. T. \& BubECR, R. C., 1978: Limnology of Irondequoit Bay, Monroe county, New York. - In: J. A. Bloomfielo (ed.) Lakes of New York State. Vol. II: Ecology of the Lakes of Western New York: 106-223. Academic Press.

Brock, T. D., 1986: A eutrophic lake, Lake Mendota, Wisconsin. - Ecological Stadies 55, SpringerVerlag,

Christie, A. E., 1974: Nutrient enrichment studies in a marl lake: Lake-on-the-mountain, Prince Edward County. - Ontario Ministry of the Environment, Researcb Report W 48.

Coveney, M. F., Cronbirg, G., Enel., M., Larsson, K. \& Olofson, L., 1977: Phytoplankton, zooplankton and bacteria-standing crop and production relationships in a eutrophic lake. Oikos 29: 5-21.

Eneil, M., 1980: The phosphorus economy of a small lake in Scania, South Sweden. - Ph. D. thesis. Institute of Limnology, Univ. of Lund.

Flett, R. J., Schindier, D. W., Hamilton, R. D. \& Campbell, N. E. R., 1980: Nitrogen fixation in Canadian Precambrian Shield lakes. - Can. J. Fish. Aquat. Sci. 37: 494-505.

Harr, T. E., Fuhs, G. W., Green, D. M., Hetulng, L. J., Smith, S. B. \& Ali en, S. P., 1978: Limnology of Canadarago Lake. - In: J. A. Bloompreso (ed.) Lakes of New York State. Vol. III. Ecology of the Lakes of East-Central New York: 130-265. Academic Press.

HorNe, A. J , 1979: Management of lakes containing $\mathrm{N}_{2}$ fixing blue-green algae. - Arch. Hydrobiol. Beib. Ergebn. Limnol. 13: 133-144.

KALFF, J. \& KNOECHEI, R., 1978: Phytoplankton and their dynamics in oligotrophic and eutrophic lakes. - Annu. Rev. Ecol. Syst. 9: 475-495.

KEATING, K. I., 1978: Blue-green algal inhibition of diatom growth: transition from mesotrophic to eutrophic community structure. - Science (Wash, DC) 199: 971-973.

King, D., 1970: The role of carbon in eutrophication. - J. Water Pollut. Control. Fed. 42: $2035-2051$.

LYNCH, M. \& SHAPRO, J., 1981: Predation, enrichment and phytoplankton community structure. Limnol. Oceanogr. 26: 86-102.

Murphy, T. P., Lean, D. R. S. \& Nalewajko, C., 1976: Blue-green algae: Their excretion of ironselective chelators enables them to dominate other algae. - Science (Wash., DC) 192: $900-902$.

Nalewajko, C., Bryant, G. \& Sreenivisa, M., 1981: Limnology of Heart Lake, Ontario. - Hydrobiologia 79: 245-253.

Nrcholus, K. H., Kennedy, W. \& Hammetт, C., 1980: A fish-kill in Heart Lake, Ontario, associated with the collapse of a massive population of Ceratium birundinella (Dinophyceae). Freshrwat. Biol. 10: 553-561.

PREPAS, E. E. \& VICKERY, J., 1984: Seasonal changes in total phosphorus and the role of internal loading in Western Canadian lakes. - Verh. Internat. Verein. Limnol. 22: 303-308.

PRePas, E. E. \& TREw, D. O., 1983: Evaluation of the phosphorus-chlorophyll relationship for lakes off the Precambrian Shield in western Canada. - Can. J. Fisb. Aquat. Sci. 40:27-35.

Porter, K., 1973: Selective grazing and differential digestion of algae by zooplankton. - Nature 244: $179-180$.

Reynolds, C. S. \& Walsby, A. E., 1975: Water-blooms. - Biol. Rev. 50: 437-481.

Rexnolds, C. S., Jaworski, G. H. M., CMmech, H. A. \& Leedale, F., 1981: On the annual cycle of the blue-green alga Microsystis deruginosa KÜTz. emend Elenkin, - Phil. Trans. R. Soc. Lond. B. 292: $419-477$.

RILEY, E. T. \& PrepAs, E. E., 1984: Role of internal phosphorus loading in two, shallow, productive lakes in Alberta, Canada. - Can. J. Fish. Aquat. Sci. 41: 845-855.

Schaffer, W. R. \& OGiesby, R. T., 1978: Limnology of eight finger lakes: Hemlock, Candice, Hemeoye, Keuka, Seneca, Owasco, Skaneateles and Otisco. - In: J. A. Bloomfrelo (ed.) Lakes of New York State. Vol. I. Ecology of the Finger Lakes: 313-470. Academic Press.

Schinduer, D. W., 1977: Evolution of phosphorus limitation in lakes. - Science (Wash., DC) 195: 260-262.

SHAPro, J, 1973: Blue-green algae: why they become dominant. - Science (Wash., DC) 179: 382-384.

- 1984: Blue-green algal dominance in lakes: the role and management significance of $\mathrm{pH}$ and $\mathrm{CO}_{2 .}$ - Int. Revue ges. Hydrobiol. 69: 765-780. 
SMrTH, V. H., 1983: Low nitrogen to phosphorus ratios favor dominance by blue-green algae in lake phytoplankton. - Science (Wash., DC) 221: 669-671.

- 1986: Light and nutrient effects on the relative biomass of blue-green algae in lake phytoplankton. - Can. J. Fish. Aquat. Sci. 43: 148-153.

TRIMBEE, A. M., 1983: The phytoplankton dynamics of a small reservoir. - Ph. D. thesis, McMaster University, Hamilton, Ontario.

Trimber, A. M. \& Harrus, G. P., 1984: Phytoplankton dynamics of a small reservoir: use of sedimentation traps to quantify the loss of diatoms and recruitment of summer bloom-forming blue-green algae. - J. Plankton Res. 5: 897-918.

Trmare, A. M. \& Prepas, E. E., 1987: Evaluation of total phosphorus as a predictor of the relative importance of blue-green algae with emphasis on Alberta lakes. - MS in press.

Trew, D. O., Yonge, E. I. \& Kaminski, R. P., 1981: A trophic assessment of nine lakes in the Cold Lake Region. - Alberta Environment Interim Report. Pollution Control Division, Water Quality Control Branch.

TREw, D. O, 1985: The impact of the proposed Cold River flow reductions on the water quality of Pierce Lake, Lepine Lake and Lac Des Isles. Cold Lake-Beaver River Long Term Water Management Study. Appendix H. Local Supply Alternative. - Alberta Environment. Pollution Control Division, Water Quality Control Branch.

Willen, T., 1975 (ed.): Vättern, Vänern, Mälaren, Hjälmaren, en Oversikt. - Statens naturvardsverk publication 1976.

Authors' address:

Department of Zoology, University of Alberta, Edmonton, Alberta T6G 2E9, Canada. 